\title{
Resistance to Fusarium Wilt Race 2 in the Pisum Core Collection
}

\author{
Kevin E. McPhee, ${ }^{1}$ Abebe Tullu, John M. Kraft, ${ }^{2}$ and Fred J. Muehlbauer \\ U.S. Department of Agriculture, Agricultural Research Service, Grain Legume Genetics and Physiology \\ research Unit, Room 303 Johnson Hall, Washington State University, Pullman, WA 99164-6434
}

\begin{abstract}
AdDitional Index words. Pisum sativum, Fusarium oxysporum, fungal disease
Abstract. Plant breeders must be aware of sources of resistance to pathogens that affect their crops. Fusarium wilt caused by Fusarium oxysporum Schl. f. sp. pisi Snyd. \& Hans. is a fungal disease that affects peas and is important worldwide. Resistance to the different races of the pathogen has been identified in adapted germplasm and from specific accessions in the United States World Collection of peas (Pisum sativum L.). The goal of this study was to evaluate the resistance to fusarium wilt race 2 in the Pisum core collection. Of the 452 accessions screened, $62(14 \%)$ were resistant. The resistant accessions included accessions from $P$.s. ssp. elatius that were collected from 24 different countries. The wide distribution of resistance around the world precludes the identification of any single country or region as a source of resistance. Of the 62 accessions resistant to race 2,39 are also resistant to race 1 based on data obtained from GRIN. One of the wild progenitors, PI 344012, possessed resistance to races 1 and 2.
\end{abstract}

Germplasm collections are valuable sources of resistance to numerous plant pests. The value and use of cool season food legume germplasm collections as sources of desirable traits has been reviewed by several authors (Ali et al., 1994; Muehlbauer, 1992, Muehlbauer et al., 1994). Core collections, as subsets of germplasm collections, have been developed for the grain legumes including chickpea (Cicer arietinum L.), lentil (Lens culinaris Medik.), and pea (Pisum sativum L.) specifically to aid researchers in identifying regions of the world where genes of interest may be found (Simon and Hannan, 1995).

Fusarium wilt, caused by Fusarium oxysporum Schl. f. sp. pisi Snyd. \& Hans., is an important fungal disease of peas in most pea growing regions around the world. Six races have been described. Race 1 was discovered in Wisconsin in 1924 (Linford, 1928) and was later found in Washington, Idaho and New York (Wade et al., 1938). Soon after resistance to race 1 was incorporated into cultivars, a second race which overcame resistance to race 1 was discovered (Snyder and Walker, 1935). This second race, designated race 2 , was called near wilt since symptoms became noticeable later in the season than for race 1 . Races 1 and 2 were the only economically important wilt races in the United States until race 5 appeared in northwestern Washington in 1963 (Haglund and Kraft, 1970). Races 1 and 2 are known to occur throughout the world, while races 5 and 6 are only important in western Washington State (Haglund and Kraft, 1979). Race 3 is present in Europe and England while race 4 is found in Canada (Hagedorn, 1984).

Near wilt is an increasing problem in southwestern Washington and northeastern Oregon. The disease is nearly always associated with short crop rotations, root rots and nematode damage. Secondary cortical decay often occurs with race 2 of fusarium wilt when other fungal diseases invade the root through existing wounds (Hagedorn, 1984).

Genetic resistance to races $1,2,5$, and 6 is conferred by different single dominant genes (Hagedorn, 1984) and is available in numerous germplasm releases (Haglund and Anderson, 1987;

Received for publication on 3 Nov. 1997. Accepted for publication 24 Sept. 1998. The cost of publishing this paper was defrayed in part by the payment of page charges. Under postal regulations, this paper therefore must be hereby marked advertisement solely to indicate this fact

${ }^{1}$ To whom reprint requests should be addressed.

${ }^{2}$ USDA-ARS, Irrigated Agriculture Research and Extension Center, $24106 \mathrm{~N}$. Bunn Road, Prosser, WA, 99350-9687.
Kraft and Giles, 1976; Kraft and Tuck, 1986). Resistance to race 2 was first discovered in an adapted breeding line in 1945 by researchers in Wisconsin (Hare et al., 1949). A selection from this line was later released as Delwiche Commando (Canner, 1945).

Genetic resistance is often concentrated in certain groups of germplasm that originate from a specific region in the world. It is valuable to understand where these regions are located such that the accessions from those areas can be fully exploited for their resistance. The goals of the current study were to 1) identify individual accessions in the Pisum core collection that possess resistance to race 2 of fusarium wilt and 2) determine if resistance was concentrated in a specific region of the world.

\section{Materials and Methods}

The Pisum core collection is composed of 504 accessions from 60 countries. However, due to insufficient quantities of seed, only 452 accessions were available for screening at the time of this study. Seed for each of the accessions were received from the USDA-ARS, Regional Plant Introduction Station (RPIS), Pullman, Wash. Two subspecies of Pisum sativum are represented in the core collection: P.s. ssp. abyssinicum A. Br. (8 accessions) and P.s. ssp. elatius Bieb. (13 accessions) (Table 1).

Ten to twelve seeds of each of the accessions were planted in trays containing sterile coarse perlite. Dark Skin Perfection, Little Marvel, and New Season, all having known reactions to race 2 (Hagedorn, 1984; Haglund and Anderson, 1987), were used as controls with each set of lines tested. Plants with three or four nodes were carefully removed from the perlite and submerged in a spore suspension for $5 \mathrm{~min}$. While submerged in the spore suspension, about $1 / 4$ to $1 / 5$ of the basal roots on each seedling were removed with scissors. The plants were inoculated and replanted into the perlite and watered with Peter's solution (15-10-30) diluted to 1 $\mathrm{mg} \cdot \mathrm{L}^{-1}$ nitrogen (Scott's-Sierra Horticultural Products Co., Marysville, Ohio) plus micronutrients (Peter's Fertilizer Products, W.R. Grace and Co., Allentown, Pa.) daily. Air temperature in the greenhouse was 24 to $28^{\circ} \mathrm{C}$. All accessions were screened in two replications. The plants were scored for the disease reaction 3 and 6 weeks after inoculation.

The primary inoculum was derived from a single spore culture of Fusarium oxysporum f. sp. pisi race 2. Cultures were grown in a liquid media as described in Haglund (1989), Bhatti (1990), and 
Table 1. Distribution of resistance to fusarium wilt race 2 among accessions in the Pisum core collection.

\begin{tabular}{|c|c|c|c|c|c|c|}
\hline \multirow[b]{2}{*}{ Genus } & \multirow[b]{2}{*}{ Species } & \multirow[b]{2}{*}{ Subspecies } & \multirow{2}{*}{$\begin{array}{c}\text { Accession } \\
\text { (no.) }\end{array}$} & \multicolumn{3}{|c|}{ Reaction to race 2} \\
\hline & & & & Resistant & Mixed & Susceptible \\
\hline$\overline{\text { Pisum }}$ & sativum & abyssinicum & 8 & 0 & 7 & 1 \\
\hline Pisum & sativum & elatius & 13 & 2 & 8 & 3 \\
\hline Pisum & sativum & & 431 & 60 & 231 & 140 \\
\hline Total & & & 452 & 62 & 246 & 144 \\
\hline
\end{tabular}

Tullu (1996). Conidial concentration was adjusted to $1 \times 10^{6}$ spores/mL as measured by a hemacytometer.

After disease development the number of healthy plants and the total number of plants inoculated were counted. Accessions with $>90 \%$ of the plants showing no visible symptoms such as stunting, discoloration of the growing tip, or chlorosis and death of alternate stipules, were classified as resistant. Accessions with $20 \%$ to $89 \%$ asymptomatic plants were classified as mixtures. Accessions with $<20 \%$ asymptomatic plants were classified as susceptible. The average of both replications were used to classify the accessions into resistant, mixed, and susceptible groups.

Data for resistance to fusarium wilt race 1 and tolerance to aphanomyces root rot for the accessions in the Pisum core collection was obtained from the Germplasm Resources Information Network (GRIN) (http:/www.ars-grin.gov/npgs/). This information was combined with the data for resistance to race 2 to evaluate if an association existed between resistance to races 1 and 2 as well as between resistance to race 2 and tolerance to aphanomyces root rot caused by Aphanomyces euteiches f. sp. pisi Drechs.

\section{Results}

The response of the three differential check lines-Dark Skin Perfection, Little Marvel, and New Season-to infection with fusarium wilt race 2 was as expected (Hagedorn, 1984). Dark Skin Perfection, which is resistant to race 1 but susceptible to race 2, had an average of $20 \%$ survival. Little Marvel, which is susceptible to both races, had an average survival rate of $23 \%$; while New Season, which is resistant to both races, had an average survival rate of $80 \%$. The lack of complete susceptibility or resistance in the differential lines may have come about via escaping infection in the case of the susceptible lines or, in the case of the resistant lines, death may have been due to infection by other fungi or from excessive loss of roots during inoculation. The classification of the accessions into the three categories was relatively conservative because only those accessions with fewer symptomatic plants than the resistant checks were classified as resistant and those with equal or fewer asymptomatic plants were classified as susceptible.

Of the 452 accessions, 62 (14\%) were classified as resistant, $246(54 \%)$ as mixtures of asymptomatic and symptomatic plants, and $144(32 \%)$ as susceptible (Table 1). Pisum sativum ssp.elatius and P.s. ssp. abyssinicum are commonly regarded as the wild progenitors of common pea. Only 2 of the 21 wild subspecies accessions (PI 344010 and PI 344012) showed resistance to race 2 and both were from P.s. ssp. elatius. PI 344012, collected in Greece in 1969, was also resistant to race 1 (Table 2).

The large number of accessions (54\%) which showed a mixed reaction to race 2 was not unexpected given the nature of how the plant introduction accessions are collected. Many of the accessions are landraces (natural mixtures) or mixtures of seed which are grown by farmers in many of the developing countries.

Data for resistance to race 1 of fusarium wilt was obtained from GRIN and compared to the data on resistance to race 2 . Of the 62 accessions resistant to race 2, 39 were also resistant to race 1,13 were resistant to race 2 but showed a mixed reaction to race 1 , and 10 with resistance to race 2 were susceptible to race 1 .

No association was detected between resistance to race 2 and tolerance to aphanomyces root rot. Only 387 accessions could be compared for an association between race 2 and aphanomyces root

Table 2. PI accessions of pea which show resistance to races 1 and 2 of fusarium wilt.

\begin{tabular}{|c|c|c|c|}
\hline \multirow[b]{2}{*}{ Accession } & \multirow{2}{*}{$\begin{array}{l}\text { Country } \\
\text { of origin }\end{array}$} & \multicolumn{2}{|c|}{ Wilt reaction } \\
\hline & & Race 1 & Race $2^{z}$ \\
\hline PI 117264 & Turkey & $\mathrm{R}$ & 100 \\
\hline PI 121976 & India & $\mathrm{R}$ & 100 \\
\hline PI 125672 & Austria & $\mathrm{R}$ & 95 \\
\hline PI 163129 & India & $\mathrm{R}$ & 96 \\
\hline PI 164614 & India & $\mathrm{R}$ & 90 \\
\hline PI 166084 & India & $\mathrm{R}$ & 100 \\
\hline PI 179451 & Syria & $\mathrm{R}$ & 94 \\
\hline PI 179459 & Turkey & $\mathrm{R}$ & 90 \\
\hline PI 180693 & Germany & $\mathrm{R}$ & 100 \\
\hline PI 180699 & Germany & $\mathrm{R}$ & 90 \\
\hline PI 181958 & Syria & $\mathrm{R}$ & 100 \\
\hline PI 184130 & Yugoslavia & $\mathrm{R}$ & 90 \\
\hline PI 210561 & Soviet Union & $\mathrm{R}$ & 95 \\
\hline PI 244150 & Netherlands & $\mathrm{R}$ & 90 \\
\hline PI 261677 & Netherlands & $\mathrm{R}$ & 100 \\
\hline PI 269777 & England & $\mathrm{R}$ & 96 \\
\hline PI 269804 & England & $\mathrm{R}$ & 100 \\
\hline PI 269816 & England & $\mathrm{R}$ & 100 \\
\hline PI 269825 & England & $\mathrm{R}$ & 100 \\
\hline PI 271121 & Germany & $\mathrm{R}$ & 100 \\
\hline PI 272175 & Germany & $\mathrm{R}$ & 100 \\
\hline PI 274308 & Pakistan & $\mathrm{R}$ & 100 \\
\hline PI 280617 & Estonia & $\mathrm{R}$ & 100 \\
\hline PI 285718 & Poland & $\mathrm{R}$ & 95 \\
\hline PI 285719 & Poland & $\mathrm{R}$ & 96 \\
\hline PI 286430 & Nepal & $\mathrm{R}$ & 90 \\
\hline PI 314803 & Australia & $\mathrm{R}$ & 100 \\
\hline PI 324706 & Romania & $\mathrm{R}$ & 100 \\
\hline PI 343958 & Turkey & $\mathrm{R}$ & 91 \\
\hline PI 343968 & Turkey & $\mathrm{R}$ & 100 \\
\hline PI 343988 & Turkey & $\mathrm{R}$ & 93 \\
\hline PI $344012^{y}$ & Greece & $\mathrm{R}$ & 100 \\
\hline PI 347457 & India & $\mathrm{R}$ & 90 \\
\hline PI 347496 & India & $\mathrm{R}$ & 95 \\
\hline PI 356984 & India & $\mathrm{R}$ & 95 \\
\hline PI 356986 & India & $\mathrm{R}$ & 90 \\
\hline PI 390795 & Peru & $\mathrm{R}$ & 90 \\
\hline PI 409031 & Germany & $\mathrm{R}$ & 95 \\
\hline PI 505111 & Syria & $\mathrm{R}$ & 100 \\
\hline
\end{tabular}

${ }^{\mathrm{z}}$ Reaction to race 2 is the percent of plants with resistance.

${ }^{\mathrm{y}}$ This accession is from the subspecies Pisum sativum ssp. elatius. 
Table 3. Distribution of resistance ( $\mathrm{R}=$ resistant, $\mathrm{S}=$ susceptible) to fusarium wilt race 2 in the Pisum core collection by country.

\begin{tabular}{|c|c|c|c|c|c|}
\hline Country & $\begin{array}{l}\text { Accession } \\
\text { (no.) }\end{array}$ & $\mathrm{R} /$ mixed/S & Country & $\begin{array}{l}\text { Accession } \\
\text { (no.) }\end{array}$ & $\mathrm{R} /$ mixed/S \\
\hline Afghanistan & 16 & $5 / 2 / 9$ & Albania & 2 & $0 / 2 / 0$ \\
\hline Australia & 10 & $2 / 3 / 5$ & Austria & 2 & $1 / 1 / 0$ \\
\hline Brazil & 2 & $1 / 1 / 0$ & Bulgaria & 3 & $0 / 2 / 1$ \\
\hline Canada & 4 & $0 / 1 / 3$ & Chile & 1 & $0 / 1 / 0$ \\
\hline China & 9 & $0 / 8 / 1$ & Costa Rica & 2 & $0 / 2 / 0$ \\
\hline Cyprus & 2 & $0 / 1 / 1$ & Czechoslovakia & 13 & $1 / 6 / 6$ \\
\hline Denmark & 4 & $0 / 3 / 1$ & Ecuador & 2 & $0 / 2 / 0$ \\
\hline Estonia & 1 & $1 / 0 / 0$ & Ethiopia & 38 & $0 / 26 / 12$ \\
\hline Finland & 9 & $0 / 7 / 2$ & France & 10 & $1 / 3 / 6$ \\
\hline Germany & 21 & $7 / 7 / 7$ & Greece & 11 & $2 / 6 / 3$ \\
\hline Guatemala & 3 & $0 / 3 / 0$ & Guinea & 1 & $0 / 0 / 1$ \\
\hline Honduras & 1 & $0 / 0 / 1$ & Hungary & 19 & $0 / 6 / 13$ \\
\hline India & 50 & $8 / 33 / 9$ & Indonesia & 1 & $0 / 1 / 0$ \\
\hline Iran & 9 & $0 / 7 / 2$ & Iraq & 1 & $0 / 1 / 0$ \\
\hline Israel & 8 & $0 / 6 / 2$ & Japan & 2 & $0 / 1 / 1$ \\
\hline Latvia & 1 & $0 / 0 / 1$ & Lebanon & 1 & $0 / 1 / 0$ \\
\hline Malaysia & 4 & $0 / 3 / 1$ & Mali & 2 & $0 / 2 / 0$ \\
\hline Mexico & 5 & $0 / 4 / 1$ & Nepal & 7 & $1 / 5 / 1$ \\
\hline Netherlands & 14 & $2 / 6 / 6$ & New Zealand & 5 & $0 / 1 / 4$ \\
\hline Nigeria & 1 & $0 / 1 / 0$ & Norway & 1 & $0 / 1 / 0$ \\
\hline Pakistan & 11 & $3 / 7 / 1$ & Paraguay & 1 & $0 / 1 / 0$ \\
\hline Peru & 5 & $1 / 2 / 2$ & Poland & 17 & $4 / 5 / 8$ \\
\hline Romania & 1 & $1 / 0 / 0$ & Rwanda & 1 & $0 / 0 / 1$ \\
\hline Spain & 10 & $0 / 3 / 7$ & Soviet Union & 15 & $1 / 5 / 9$ \\
\hline Sudan & 1 & $0 / 0 / 1$ & Sweden & 11 & $1 / 6 / 4$ \\
\hline Syria & 7 & $3 / 3 / 1$ & Taiwan & 1 & $0 / 1 / 0$ \\
\hline Thailand & 1 & $0 / 1 / 0$ & Turkey & 28 & $8 / 16 / 4$ \\
\hline Uganda & 1 & $1 / 0 / 0$ & Ukraine & 2 & $0 / 0 / 2$ \\
\hline United Kingdom & 19 & $5 / 11 / 3$ & United States & 12 & $1 / 5 / 6$ \\
\hline Venezuela & 1 & $0 / 1 / 0$ & Yugoslavia & 9 & $1 / 5 / 3$ \\
\hline Totals & 231 & $40 / 124 / 68$ & Totals & 221 & $22 / 122 / 76$ \\
\hline
\end{tabular}

rot due to incomplete data in GRIN. The average root damage caused by Aphanomyces for those lines resistant to race 2 was $69.2 \%$, while those lines with either a mixed or susceptible reaction to race 2 had an average root damage of $67.9 \%$.

\section{Discussion}

An understanding of the improvement status (cultivated type, cultivar, landrace, wild progenitor, etc.) of the resistant PI accessions would lend insight to the source and origin of resistance. Unfortunately, the improvement status of only half the resistant accessions could be determined with reasonable confidence because of insufficient reports left from the original collection. Of the 62 accessions resistant to race 2, 11 were cultivars; 15 were cultivated types; 2 were from the subspecies P.s. ssp. elatius, PI 344010, and PI 344012; 1 was a genetic line from Lamprect (\#368); and 1 was a cross between P.s. ssp. elatius and 'Clamart', a breeding line in England. The improvement status of the remaining 32 accessions is unknown. Due to the large number of accessions with unknown improvement status and the fact that resistance was found in accessions which certainly differ in the degree to which they were developed, it is difficult to draw any conclusions regarding the origin of resistance to fusarium wilt race 2 .

No specific region of the world could be identified as a source of resistance to race 2 of fusarium wilt since at least one accession from 24 of the 60 countries represented in the core collection showed resistance (Table 3). However, 33 of the 62 resistant accessions were obtained from five countries: Turkey (8), India (8), Germany (7), Afghanistan (5), and the United Kingdom (5) (Table 3). The large number of accessions classified as mixed in the collection is evident of the heterogeneous nature of germplasm accessions, particularly landraces and wild accessions. Each individual would be expected to be homozygous, however, mixtures of homozygous individuals result in heterogeneous populations. Many of the accessions show phenotypic variability and certainly contain genetic variability. That only $54 \%$ of the accessions were classified as mixtures is realistic and one could expect that the percentage would be higher.

The presence of all possible combinations of resistance and susceptibility to races 1 and 2 within the Pisum core collection was not unexpected since there is a loose association between the two loci (Grajal-Martin and Muehlbauer, 1992; Wade, 1929; Wells et al., 1949). Resistance to each of the four races of fusarium wilt found in the United States is conferred by different single dominant

Table 4. Summary of disease reactions for 407 PI accessions from the Pisum core collection to fusarium wilt races 1 and 2 .

\begin{tabular}{lcccr}
\hline & \multicolumn{3}{c}{ Race 1 reaction } & \\
\cline { 2 - 4 } Race 2 reaction & Resistant & Mixed & Susceptible & Total \\
\hline Resistant & 39 & 13 & 10 & 62 \\
Mixed & 127 & 53 & 37 & 217 \\
Susceptible & 77 & 16 & 35 & 128 \\
Total & 243 & 72 & 82 & 407 \\
\hline
\end{tabular}


genes (Hagedorn, 1984; Muehlbauer, 1992). The gene for resistance to race $1(F w)$ is located on the Pisum linkage group four, 30 map units from the Le gene (Wade, 1929). More recent evidence indicates that placement of $F w$ on linkage group four may not be correct (N. Weeden, personal communication). Grajal-Martin and Muehlbauer (1992) studied the linkage between resistance genes for race $1(F w)$ and $2(F n w)$ and reported a recombination frequency of $46 \%$ indicating independent assortment. Wells et al. (1949) also reported a loose linkage between the two loci with a recombination frequency of $40 \%$.

It has been hypothesized that the genetic resistance for common root rot, caused by Aphanomyces euteiches f.sp. pisi, and fusarium wilt may be linked (J. Kraft, personal communication). The data for resistance to common root rot was obtained from the Genetic Resources Information Network (GRIN) and combined with the data on resistance to fusarium wilt race 2 . Based on the combined data, there does not appear to be any association for the lines included in the Pisum core collection. Overall resistance/tolerance to aphanomyces root rot is quite low in the core collection. Only one accession showing resistance to fusarium wilt race 2 can be considered tolerant to aphanomyces root rot with a root damage score $<50 \%$ while two accessions showing a mixed or susceptible reaction to fusarium wilt race 2 could be considered tolerant to aphanomyces root rot. Therefore, with a nearly equal and low number of PI accessions showing resistance to both organisms and resistance to one and susceptibility to the other, it can not be concluded whether there is a direct linkage or association between the resistance genes.

This study identified 62 accessions in the Pisum core collection which were resistant to fusarium wilt race 2 . Of these accessions, 39 were also resistant to race 1 and are listed in Table 2. A complete listing of the data for the resistant accessions and the remaining accessions tested can be found at the GRIN website (http:/www.arsgrin.gov/npgs/). The resistant germplasm identified in this study will be of direct use to breeders in the development of cultivars resistant to fusarium wilt race 2 .

\section{Literature Cited}

Ali, S.M., B. Sharma, and M.J. Ambrose. 1994. Current status and future strategy in breeding pea to improve resistance to biotic and abiotic stresses, p. 540-543. In: F.J. Muehlbauer and W.J. Kaiser (eds.). Expanding the production and use of cool season food legumes. Kluwer
Academic Press, the Netherlands.

Bhatti, M.A. 1990. The effects of inoculum density and environmental factors on wilt and root rot of chickpea (Cicer arietinum $\mathrm{L}$.). $\mathrm{PhD}$ diss. Wash. State Univ., Pullman.

Canner. 1945. Wilt-resistant canning pea named for Professor E.J. Delwiche. Canner 101(15):11.

Grajal-Martin, M.J. and F.J. Muehlbauer. 1992. Linkage relationship between genes $F w$ and $F n w$. Pisum Genet. 24:52-53.

Germplasm Resources Information Network. 1997. http:/www.arsgrin.gov/npgs.

Hagedorn, D.J. 1984. Compendium of pea diseases. Amer. Phytopathol. Soc., St. Paul, Minn. p. 30-31.

Haglund, W.A. 1989. A rapid method for inoculating pea seedlings with Fusarium oxysporum f.sp. pisi. Plant Dis. 73:457-458.

Haglund, W.A. and W.C. Anderson. 1987. WSU 28 and WSU 31 pea inbred lines with resistance to specific races of fusarium wilt. HortScience 22(3):513-514.

Haglund, W.A. and J.M. Kraft. 1970. Fusarium oxysporum f.sp. pisi, race 5. Phytopathology 60:1861-1862.

Haglund, W.A. and J.M. Kraft. 1979. Fusarium oxysporum f.sp. pisi, race 6: Occurrence and distribution. Phytopathology 69:818-820.

Hare, W.W., J.C. Walker, and E.J. Delwiche. 1949. Inheritance of a gene for near-wilt resistance in the garden pea. J. Agr. Res. 78(8):239-251.

Kraft, J.M. and R.A. Giles. 1976. Registration of 74SN3, 74SN4, and 74SN5 pea germplasm. Crop Sci. 16:126.

Kraft, J.M. and J.A. Tuck. 1986. Registration of 75-786, 84-1638, and 841930 pea germplasms. Crop Sci. 26:1262-1263.

Linford, M.B. 1928. A fusarium wilt of peas in Wisconsin. Wis. Agr. Expt. Sta. Res. Bul. 85.

Muehlbauer, F.J. 1992. Use of introduced germplasm in cool-season food legume cultivar development, p. 49-73. In: Use of plant introductions in cultivar development. Part 2. CSSA Spec. Publ. 20.

Muehlbauer, F.J., W.J. Kaiser, and C.J. Simon. 1994. Potential for wild species in cool season food legume breeding. Euphytica 73:109-114.

Simon, C.J. and R.M. Hannan. 1995. Development and use of core subsets of cool-season food legume germplasm collections. HortScience 30:907.

Snyder, W.C. and J.C. Walker. 1935. Fusarium near wilt of peas. Zentralbl. Bakteriol. Parasitenkd. 91:355-378.

Tullu, A. 1996. Genetics of fusarium wilt resistance in chickpea. PhD diss. Wash. State Univ., Pullman.

Wade, B.L. 1929. The inheritance of fusarium wilt resistance in Canning peas. Wis. Res. Bul. 96. p. 1-32.

Wade, B.L., W.J. Zaumeyer, and L.L. Harter. 1938. Variety studies in relation to fusarium wilt of peas. USDA Cir. 473. p. 26

Wells, D.G., W.W. Hare, and J.C. Walker. 1949. Evaluation of resistance and susceptibility in garden pea to near wilt in the greenhouse. Phytopathology 39:771-779. 